\title{
Social Studies Teacher Candidates' Views About Information Technologies and Material Used in Social Studies Lesson
}

\author{
Mehmet ORAN ${ }^{1} \&$ Mehmet Akif KARALI ${ }^{2}$ \\ ${ }^{1}$ Department of Social Studies Education, Faculty of Education, Usak University, Turkey \\ ${ }^{2}$ Department of Social Studies Education, Faculty of Education, Marmara University, Turkey \\ Correspondence: Mehmet ORAN, Social Studies Education Department, Faculty of Education, Usak University, \\ Turkey. E-mail: mehmtoran@gmail.com.tr
}

\author{
Received: April 15, 2021 \\ Accepted: May 22, 2021 \\ Online Published: July 22, 2021 \\ doi:10.5539/ies.v14n8p51 \\ URL: https://doi.org/10.5539/ies.v14n8p51
}

\begin{abstract}
The research was prepared in order to reveal the opinions of social studies teacher candidates on the use of information technologies and materials in social studies lessons. The study group of the research consists of teacher candidates studying in the department of social studies teaching at Cukurova University in Turkey. The research was prepared in accordance with phenomenology, one of the qualitative research designs. A structured interview form, which was previously created by taking expert opinion, was used to collect data. There are 5 questions that complement each other in the interview form. The data obtained from the interview form were subjected to content analysis. The reliability of the study was calculated as $95.5 \%$ according to the reliability formula of Miles and Huberman (1994). It was concluded that the prospective teachers who participated in the research supported the use of information technologies in the social studies course. It was seen that the tools in the classroom environment as technology and material were expressed by the majority of the participants.
\end{abstract}

Keywords: information technologies, material usage, social studies

\section{Introduction}

A human being is an entity that tends to make his life easier and to have knowledge about the world he lives in. In the process from birth to death, people investigate what their situation is and how they can be better. It is important for individuals to know themselves through the answers they give to the questions, to have an idea about their environment and to realize what they can do. Individuals who are aware of what they can do gain important information about their lives through some initiatives. Knowledge is in a structure that grows by constantly being put on it. Individuals gain knowledge by being affected by many events such as the problems they encounter in the regions they live in throughout history and the experiences in their lives. With the discovery of writing, the knowledge of human history is constantly increasing, and each new information triggers the emergence of other new information.

Civilizations established in different parts of the world have contributed to human knowledge without being aware of each other. This contribution has improved considerably with the increase in transportation opportunities and the facilitation of communication. Although these means of transportation differ from primitive societies to modern societies, the transportation of information has always continued. This process, which started with the domestication of some animals, triggered the discovery of tools, with the development of tools, people provided transportation over the seas, and trade was developed by providing transportation to the whole world with the invention of large ships. As a result of all these, the world, which has turned into a global village today, has emerged.

Although each society is separated from each other with its unique structure, knowledge has continued as a common bond that unites all societies. The Renaissance and Reform movements in the European continent have been an important building block on the way to create a scientific world based on the human mind by destroying dogma information. The technology that emerged today as the common product of all humanity was born from knowledge. According to Isman (2011) technology; Although it is not a situation that arises spontaneously, it is a process that people are influenced by and that arises for their needs. The information has been proven to be correct in a number of ways and has been transformed into a regular structure and is accepted as correct unless otherwise 
proven. Demirel (1993) technology; It defines it as the application of observational and proven knowledge in achieving certain goals, solving certain problems. Based on this definition, it is important in the development of technology that the accuracy of the information has been proven.

Technology is divided into a number of different areas within itself. Information technology is one of these areas. Information technology; it can be defined as systems created by using computer and communication technologies together. All technologies, including communication and computer technologies, that enable the collection, processing, storage and transmission of information from one place to another via networks are called information technology. Today, information technologies have a great impact on societies. People organize, process, perfect the knowledge they produce and the experiences they have acquired through technology and benefit from transferring them to future generations.

Education is of great importance in transferring information technologies to future generations. Education; they are planned activities that aim to provide certain improvements in the behavior of individuals according to predetermined principles. The most important purpose of education is to train the individual effectively and to ensure the mental development of the individual (Isman, 2003). In order to bring the education to its intended state, it is necessary to include all the opportunities that can be used under the conditions of the day into the teaching process and to make the most of these opportunities. At this point, technology and technological tools are included in educational activities and it is necessary to benefit from technological opportunities in the teaching process. The tools used in the teaching process are called "instructional technology" (Sonmez, 1994; Yanpar, 2011). The purpose of using instructional technologies; accessing information, realizing an effective education, reducing educational costs, responding to the need for technological change, and providing students with the skills to use technology (Caliskan and Karadag, 2007). Since one of the aims of education is to raise individuals in line with the needs of the society, it has become necessary to educate students in accordance with the information age and taking into account the characteristics of information societies. Considering that today's individuals need to develop their skills in reaching information, correcting information, evaluating information, presenting information and communicating, technology and education and training mutually affect each other and contribute to the individual's having all these characteristics (Simsek, Ozdamar, Becit, Kilicer, Akbulut and Yildirim, 2007). Education has to teach the new technologies emerging today to individuals and to raise individuals who can use these technologies in society. At this point, technology and technological tools are included in educational activities and it is necessary to benefit from technological opportunities in the teaching process. Ozden (2003) explains the usage stages of technology opportunities in education in the world from past to present as follows:

- It was used as a visual material in education with military films in World Wars II.

- In the 1950s, television began to be used for teaching purposes and audio-visual technology departments were established in universities.

- Between 1950-1960, Ford Foundation supported education through television in the USA.

- In 1967, the American Research Institute developed individual tutorial programs called "Learning Based on Needs".

Social studies course is one of the courses that transfer information technologies to future generations. Social studies is the name of the course taught in secondary schools, covering subjects selected from different social sciences and simplified in accordance with the level of students (Donmez, 2003). This course aims to realize the social existence of the individual and to raise good citizens (Tay, 2011). The general benefits of the use of technology in the social studies course to the learning-teaching process can be expressed as follows; Technological tools enable students to reach various subjects quickly, focus on the subject and learn the subject quickly, equal opportunities in education, continuity and continuity in education, and play an active role in the learning process of the student (Isman, 2003). This research aims to reveal the views of social studies teacher candidates on the use of technology and materials in social studies lessons.

\section{Method}

The model used in the research, the study group, the tools used in data collection, data collection and data analysis sections are included under this title.

\subsection{Research Model}

The research was prepared in accordance with phenomenology, one of the qualitative research designs. In the phenomenological interview, it is aimed to reveal how the participant perceives, conceptualizes and evaluates the event or events related to the research topic. In the phenomenological interview, the researcher tries to understand how people attribute meaning to external reality (Greasley \& Ashworth, 2007). Yildirim and Simsek (2008), on the 
other hand, describe the phenomenology pattern; it is named as the studies done about the phenomena that are aware of but cannot be have in-depth information.

\subsection{Working Group}

Table 1. Personal information of social studies teacher candidates participating in the research

\begin{tabular}{ccccc}
\hline Participant & Gender & Age & Grade level & Homeland \\
\hline 1 & Female & 22 & 4 & Adana \\
2 & Male & 23 & 4 & Mersin \\
3 & Female & 22 & 3 & Nigde \\
4 & Female & 23 & 4 & Adana \\
5 & Male & 22 & 4 & Gaziantep \\
6 & Male & 22 & 4 & Ankara \\
7 & Female & 23 & 4 & Konya \\
8 & Female & 21 & 3 & Osmaniye \\
9 & Male & 23 & 4 & Aksaray \\
10 & Female & 22 & 4 & Kayseri \\
\hline
\end{tabular}

The study group of the research consists of 10 social studies teacher candidates studying at the education faculty of Cukurova University. Of the pre-service teachers participating in the research, 6 are female and 4 are male. When we look at the ages of the participants, it is seen that they are between the ages of 21-23. While determining the study group of the research, the easily accessible sampling method, one of the purposeful sampling methods, was used. Effort, cost and time savings are possible in the easily accessible sampling method (Yildirim \& Simsek, 2008). In addition, the purposeful sampling method is preferred when the subject to be researched is rich in information (Buyukozturk, Kilıc Cakmak, Akgun, Karadeniz, \& Demirel, 2008). While choosing this sample, accessibility to teacher candidates and possible answers that teacher candidates can give to questions asked within the scope of the research were taken into consideration.

\subsection{Data Collection and Tools}

As data collection tools in the research; materials such as semi-structured interview form, voice recorder, pen, paper, eraser and computer were used.

\subsection{Data Collection and Analysis}

In the research, first of all, a literature review on the use of technology and materials in the lessons was carried out. Afterwards, a semi-structured interview form to be applied to social studies teacher candidates participating in the research was prepared. The questions in the interview form were prepared in line with the opinions of 3 academicians who received expertise in the field of social studies education. The aim here is to increase the validity and reliability of the research.

The data collected using the interview form in the research were analyzed using content analysis. Content analysis involves examining the data in detail and clarifying the data (Tedmem, Palanc1, Kandemir \& Dundar, 2014). In addition, in order to achieve consensus on the codes, views were exchanged with an academician who specialized in social studies education, and the reliability of the research was determined according to the reliability formula of Miles and Huberman (1994) [Percent Consensus = Consensus / (Agreement + Disagreement) x 100). ] was calculated as $95.5 \%$.

The participants of the research were expressed as P1, P2, P3, P4, P5, P6, P7, P8, P9 and P10. The answers given by the teacher candidates participating in the research to the questions in the interview form were collected in 36 codes, then this number was reduced to 22 by associating the codes with each other. Some of these codes are: Smart board, internet, map, tablet, slide, documentary, trip, game, etc.

\section{Results}

The data obtained in the research was revealed within the framework of the answers given by the participants to the questions in the interview form. Under this heading, the findings of the social studies teacher candidates participating in the research on the use of information technologies and materials in social studies lessons are included. 
3.1 Findings on What Comes to Mind When It's About the Use of Technology and Materials in Social Studies Lessons

Table 2. Codes that come to mind when talking about technology and material use

\begin{tabular}{lc}
\hline Codes & Participant \\
\hline Smart board & $1,3,4,5,6,8,9,10$ \\
Map & $1,2,4,6,7,9$ \\
Internet & $1,3,6,9$ \\
Tablet & $2,3,7,8$ \\
Slide & $3,5,8,10$ \\
Support boks & 5,10 \\
\hline
\end{tabular}

When the answers of the social studies teacher candidates participating in the research were examined, the most expressed answer was the smart board (8). Map (6) was the second most frequently cited answer. Internet (4), tablet (4) and slide (4) responses are the third most frequently mentioned response. The least expressed answer was support books (2).

P1: The use of technology in social studies lesson, smart boards, tools and materials (map, globe) for the content of the lesson come to mind. It can also be the use of the Internet.

P2: I think the use of technology is not available in every school. I can't think of anything at the moment. But maps and tablets can be.

P8: I think that the use of technology in the social studies course is connected with the internet. Because smart boards or tablets are tools connected to the internet. Teachers can prepare slides. So we can add the use of Microsoft Office programs.

P9: So if we only think about social studies, I think it is limited. I know there are smart boards. I know that there is an EBA network that teachers use. Maps and tools can also be said.

P10: I attended classes at schools. So I can answer your question. As far as I can see, there are slides, solving questions and lectures on smart boards. In addition, while the teachers recommended supplementary books, they suggested CD or DVD supported books.

In general, in the answers given by the teacher candidates; it has been seen that smart boards, maps, tablets, images depicting the world and the EBA network are mentioned. The effect of the Fatih Project implemented for contemporary education in Turkey can be seen. The importance of using the Internet and supporting the support books in schools from virtual environments was emphasized.

3.2 Findings on How to Take Advantage of Technology and Materials in Social Studies Lesson

Table 3. Codes on how technology and materials are advantage

\begin{tabular}{lc}
\hline Codes & Participant \\
\hline Smart boards & $3,4,6,9,10$ \\
Social networks & $3,4,5,8,9$ \\
Atlases & $1,6,7$ \\
Documentaries & 1,6 \\
Maps & 2 \\
Books & 2 \\
\hline
\end{tabular}

When the answers of the social studies teacher candidates participating in the research were examined, the most expressed answers were smart boards (5) and social networks (5). These answers were followed by atlases (3) and documentaries (2). The least expressed answers were maps (1) and books (1).

P2: Frankly, I have no idea about how it is used. As a material, I can say maps. Textbooks, workbooks, are materials in themselves.

P3: I can say smart boards. It is effective in that teachers process their lessons more easily. As I said slides can be made. Maybe interaction can be provided outside of school via social networks such as Facebook and Twitter. 
P4: I think it is boring to teach lessons from textbooks. Helpful resources available on the Internet are used. Lectures are made with smart boards and interaction is provided between teachers with the help of EBA.

P6: Smart boards are used. The content of the course is supported with tools and materials. Since the social studies course is very comprehensive (history, geography, etc.), different materials are used. Atlases and documentaries are used on historical subjects.

P9: I think there is a multidimensional benefit. Smart boards are used for students to participate in the lesson. Puzzles are solved at the end of the lesson activities. I can also say that there are live broadcasts on social networks. I think you can benefit from these live broadcasts.

It is seen that teacher candidates generally adhere to smart boards and social networks in terms of benefiting from technology and materials. Atlases, documentaries, maps and workbooks have been other expressed answers.

\subsection{Findings on What Can Be Done to Make Social Studies Lesson More Effective}

Table 4. Codes about what can be done to make the social studies course more effective

\begin{tabular}{lc}
\hline Codes & Participant \\
\hline Use of current practices in the course & $1,3,8,9,10$ \\
Use of materials according to course specific & $2,8,9$ \\
Group teaching & $3,6,9$ \\
Trip & 7,10 \\
Game and activity & 5 \\
\hline
\end{tabular}

When the answers of the pre-service teachers participating in the research are examined, it is seen that five different opinions emerge. These opinions are; use of current practices in the course (5), use of course-specific materials (3), group teaching (3), excursions (2), and games and activities (1).

P1: So I think making the lesson effective depends on the teacher. I think that the lesson can be more effective if the teacher knows and applies current practices.

P2: I think the lessons can be more effective if the arrangements are made according to the course topics. Materials should be prepared specific to the course.

P5: In my opinion, technological tools should be increased more and their use should be expanded. I think that students should be able to participate in the lesson. Events can be done. Teaching can be done by playing games. At the end of research assignments, a product can be created to attract students' attention.

P6: In order for the lesson to be effective, teaching can be done in groups. Students are made to sit in clusters. I think it is important for all students to be close to the technological tools and materials to be used and to see them clearly.

P7: I think trips can be made. Instead of teaching in a continuous classroom environment, field trips can be made. The characteristics of the place we live in are also suitable for this. Museum trips, historical trips, natural field trips can be made. In my opinion, the lessons taught in the classroom environment become monotonous.

In this question, teacher candidates focused on the subject of students' participation in the lesson. Every pre-service teacher participating in the research agreed that practices should be made to activate the student's participation in the lesson.

3.4 Findings Regarding Whether Technology and Materials Used in Social Studies Course Provide Permanent Learning

Table 5. Codes on whether the technology and materials used in the social studies course provide permanent learning

\begin{tabular}{lc}
\hline Codes & Participant \\
\hline Yes & $1,2,3,4,5,6,7,8,9,10$ \\
-A more active classroom environment & $2,4,5,7,8,9$ \\
-Appeal to more sensory organs & $1,4,6,9,10$ \\
-Easier recall of information & 3,5 \\
\hline
\end{tabular}


P1: I think yes. In other words, I think that the more sense organs are addressed, the more permanent the information will be.

P4: Yes. Because there is no ordinary monotonous educational environment. Seeing and touching the materials will increase the permanence of the information. The use of technology will also make students active in the lesson.

P5: Of course. The reason is this; If the teacher only lectures, the information heard remains in the air. However, information will be more likely to be remembered if technology and materials are used.

P8: It certainly does. In other words, there will be a more active classroom, and the teacher's work will be easier.

P9: I think it will. All students already know and use technology. I think it would be better for them to use it for the lesson rather than just using it. The materials are very effective. Because you can see and touch. Some materials have sound and they are beautiful. I saw a baby talking in class once. That doll caught the attention of the students and they listened to the lesson better.

When the answers of the social studies teacher candidates participating in the research were examined, all of the participants expressed positive opinions about the use of technology and materials in the lesson. They stated that the use of technology and materials in the social studies lesson saved the lesson from monotony and created a more active environment, and the use of materials in the lesson increased the efficiency of the lesson by appealing to much more sense organs. In addition, it was emphasized that the information was easier to remember thanks to the technology and materials used in the lesson.

3.5 Findings Regarding the Adequacy of Technology and Materials in the Educational Environment

Table 6. Codes on whether the technology and materials in the educational environment are sufficient

\begin{tabular}{lc}
\hline Codes & Participant \\
\hline I don't think & $1,2,3,5,6,7,8,9,10$ \\
I think partially & 4 \\
\hline
\end{tabular}

Only one of the 10 social studies teacher candidates participating in the research thinks that the technology and materials in the educational environment are partially sufficient. Five social studies teacher candidates think that the technology and materials in the educational environment are insufficient.

P4: It may be partially sufficient, but I think it should definitely be improved. It shouldn't stay at this level too long. Every classroom should have the necessary facilities. We live in Adana, let alone the education tools, even the air conditioners sometimes do not work to cool off in the summer. How will the course be taught in this environment? I think these problems should be fixed.

P6: I don't think so. There are only smart boards and maps. Schools have computer rooms, but I don't know if they are used all the time. I don't know how open the internet is for student use.

P7: I don't think so. Because the opportunities in public schools are somewhat limited. However, there are very good opportunities in private schools. In my opinion, adequate education is not given with smart boards and projection devices in schools.

P9: I don't think so. In other words, there is a smart board and if there is no internet, only the course activities that are done at home can be used. I don't know exactly if there is internet on smart boards. But I think the whole school should have an internet network that can be used in common. Libraries are already empty with the development of social networks. These books are available to read online. But these are not done in schools, of course.

P10: I think it is not enough. It seems like it's up to the teachers' dedication. So there is a tool, but it is not very effective when its use depends on what you want. I think there should be a law about it. I think that teachers should constantly use smart boards, other devices, speakers, maps and figures, and these tools should be developed.

The answers given by the participants are that the technology and materials in the schools are not at a sufficient level and should be improved. This result creates a field for further studies. What kind of materials can be developed, how technological tools can be increased, and comparisons with the materials used in the educational environments of developed countries can support new studies. 


\section{Discussion, Conclusion and Suggestions}

It is a field in which information technology and materials are discussed by many authors from different perspectives and works are presented. Undoubtedly, every study is very valuable and has been beneficial to the scientific world. With the advancement of technology, the subject of information technologies and materials has made its importance felt in almost every field from transportation to food, from health to education. What distinguishes our study from other studies is that it evaluates the subject of science, technology and material within the scope of social studies course and deals with the subject in a specific sense. When compared with the works of the authors who deal with the subject of information technologies and materials both in the field of education and in different fields, it is seen that this study has similar and different aspects.

Kir (2012) tried to determine the problems faced by information technology teachers working in primary schools in his master's thesis titled "The Approaches of Information Technology Teachers Working in Primary Schools to the Problems of Information Technology Education (Istanbul Example)". At the end of the study, it was revealed that the teachers mostly suffered from the families' approaches to the lesson, physical environments and general evaluations. While the study presented by Kir is a study for the science technology course, our study is a study for the field of social studies. In this respect, Kir's study differs from our study in terms of its field.

Kandemir, Ozturk, and Alper (2014) aimed to evaluate the information technologies and software course within the scope of the student proficiency criteria determined by international organizations operating in the fields of educational technologies in their article titled "An International View on Information Technologies and Software Course Outcomes". At the end of the research, it has been revealed that students who take information technologies and software courses are better at noticing what information they need. In addition, it has been revealed that the students who take this course have better knowledge from which sources, how to reach reliable information, decision-making, and use of high-level technology. What distinguishes this study from ours is that the study group is different. In our study, the study group consisted of social studies teacher candidates, while in this study, the study group consisted of students.

Akbaba and Erbas (2019) aimed to develop a reliable and valid measurement tool that will enable them to measure their self-efficacy in designing and using information technology supported materials in their article titled "Self-Efficacy Scale for Designing and Using Information Technology Supported Material: Validity and Reliability Studies". At the end of the study, it was revealed that the structure of the scale was acceptable. The study carried out by Akbaba and Erbas is completely different from our study in terms of method.

Dere and Ates (2020) examined in depth the observations and experiences of social studies teachers regarding the use of technological tools and materials in social studies lessons in their article titled "The Use of Technological Tools and Materials in Social Studies Lessons: A Case Study". At the end of the research, the teachers who participated in the research stated that they see technology as important and necessary and that they follow the technology up-to-date and that they also benefit from technological materials in their lessons. This study is similar to our study in terms of handling the subject. The difference between the two studies is that the study group is different.

The common side of all the studies mentioned above is that information technology is beneficial for both students and society. In this work, the subject of information technologies material was considered important and necessary by social studies teacher candidates. If we talk about the results of our research:

The research revealed the opinions of social studies teacher candidates on the use of technology and materials in social studies lessons. Social studies course is a blending of many different fields due to its content. It has been emphasized by previous studies that it is difficult to gain knowledge, skills and attitudes of history, geography and other social sciences in the traditional classroom environment. The effect of classroom environments, which will be organized in accordance with the contemporary education approach, on the permanence of learning has been revealed within the scope of the research. Smart boards and other technological devices used in educational environments in Turkey are effective but need to be developed and differentiated. The preparation of the educational environments in accordance with the conditions of the region and the preparation of the necessary technological tools and materials show that the education process will work more healthily. Pre-service teachers emphasized that the use of technology and materials in social studies lessons is not standard and varies according to schools. Another important issue is that teacher candidates have skills in using technological tools.

Based on the results obtained, the following suggestions were made:

- By increasing the number of games and activities in the social studies lesson, students can be more active in the lesson. 
- The number of learning by visiting and seeing can be increased by organizing trips to museums or historical buildings. Thus, more permanent learning can be achieved.

- Students can be provided with a sense of belonging to the course by giving more responsibilities of students in the courses.

- The number of group work can be increased in the lessons.

- Seminars can be given to teacher candidates on the use of technology in order to further increase efficiency in the lessons.

- This study is not limited to social studies teacher candidates, but can also be carried out with teachers and students.

- Similar studies can be carried out in other fields as well.

\section{References}

Akbaba, B., \& Erbas, S. (2019). Self-efficacy scale for designing and using information technology supported materials: validity and reliability studies. Turkish Journal of Educational Sciences, 17(1), 174-194.

Buyukozturk, S., Kilic Cakmak, E., Akgun, O. E., Karadeniz, S., \& Demirel, F. (2008). Scientific research methods. Ankara: Pegem A Publications.

Caliskan, N., \& Karadag, E. (2007). Basic concepts. In M. Sarıtas (Ed.), Instructional Technologies and Material Design. Ankara: Pegem A Publications.

Demirel. (1993). Educational terms dictionary. Ankara: Usem Publications.

Dere, I., \& Ates, Y. (2020). The use of technological tools and materials in social studies courses: A case study, Journal of Erzincan University Faculty of Education, 22(2), 496-514.

Donmez, C. (2003). Social sciences and social studies. In C. Sahin (Ed.), Subject Area Textbook Review Guide Social Studies (pp. 31-41). Ankara: Gunduz Education Publications.

Greasley, K., \& Ashworth, P. (2007). The phenomenology of "approach to studying": The University Student's Studies within the Lifework. British Educational Research Journal, 32, 819-843. https://doi.org/10.1080/01411920701656977

Isman, A. (2003). Instructional technologies and material Development. Istanbul: Exchange Publications.

Isman, A. (2011). Instructional technologies and material design. Ankara: PegemA Publications.

Kandemir, T., Ozturk, H. T., \& Alper, A. (2014). An international review of objects of informational technology and software course. Conference: 8th International Computer \& Instructional Technologies Symposium, Edirne.

Kir, H. (2012). The approaches of information technologies teachers who work in primary schools to the issues of information technologies education (a case study in Istanbul) (Master thesis, Bahcesehir University, Institute of Science and Technology, Department of Information Technologies, Istanbul).

Miles, M. B., \& Huberman, A. M. (1994). Qualitative data analysis: An expanded sourcebook. Thousand Oaks, CA: Sage Publication.

Ozden, M. Y. (2003). Technology and Education: Country Experiences and Lessons for Turkey. III. Internet Usage Symposium in Turkey.

Simsek, A., Ozdamar, N., Becit, G., Kilicer, K., Akbulut, Y., \& Yildirim, Y. (2007). Current trends in educational technology research in Turkey. Selcuk University Journal of Social Sciences Institute, 19, 439-458.

Sonmez, V. (1994). Teaching social studies. Ankara: PegemA Publications.

Tay, B. (2011). The past, present and future of social studies education. In R. Turan (Ed.), Fundamentals of Social Studies (2nd ed., pp. 1-20). Ankara: PegemA Publications.

Tedmem, Z. S., Palanci, M., Kandemir M., \& Dundar, H. (2014). Tendencies of the researches published in education and science journal: Content analysis. Education and Science, 173(39), 430-453.

Yanpar, Y. T. (2011). Instructional technologies and material design (10th ed.). Ankara: Anı Publishing.

Yildirim, A., \& Simsek H. (2008). Qualitative research methods in the social sciences. Ankara: Seckin Publishing. 


\section{Copyrights}

Copyright for this article is retained by the author(s), with first publication rights granted to the journal.

This is an open-access article distributed under the terms and conditions of the Creative Commons Attribution license (http://creativecommons.org/licenses/by/4.0/). 